\title{
QUALITY OF LIFE COMPARATION IN METASTATIC BONE DISEASE PATIENT BEFORE AND AFTER SURGERY IN DR. SOETOMO GENERAL HOSPITAL
}

\author{
Ferdiansyah $^{1 *}$, Mouli Edward ${ }^{1}$, Muhammad Hardian Basuki ${ }^{1}$, Rizky Agung Satria ${ }^{2}$ \\ ${ }^{1}$ Staff of Orthopaedic and Traumatology Department, Faculty of Medicine, Universitas \\ Airlangga, Dr Soetomo General Hospital, Surabaya \\ ${ }^{2}$ Resident of Orthopaedic and Traumatology Department, Faculty of Medicine, Universitas \\ Airlangga, Dr Soetomo General Hospital, Surabaya \\ *Correspondence: Ferdiansyah, Staff of Orthopedic and Traumatology Department, Faculty of \\ Medicine, Universitas Airlangga, Jl. Mayjen Prof. Dr. Moestopo 6-8, Surabaya \\ E-mail: ferdyortho@yahoo.com
}

\begin{abstract}
ABSTRAK
Latar Belakang: Penyakit tulang metastasis merupakan proses patologis tulang yang diakibatkan oleh penyebaran keganasan primer organ lain. Tulang menduduki urutan ke tiga organ yang menjadi lokasi metastasis setelah paru-paru dan hati. Insidensi penyakit tulang metastasis beragam, berkisar antara $20-75 \%$ tergantung keganasan primernya. Saat ini, operasi menjadi pilihan dalam penanganan penyakit tulang metastasis. Tindakan operasi dapat bertujuan untuk kuratif maupun paliatif. Tindakan operasi dapat menghilangkan rasa sakit, mengembalikan fungsi, kontrol fokus metastasis lokal dan juga stabilisasi mekanik tulang. Berdasarkan hal tersebut, keuntungan tindakan operatif bagi pasien dengan penyakit tulang metastasis penting untuk diketahui, disamping adanya risiko tindakan operasi yang dapat terjadi.
\end{abstract}

Tujuan: Membuktikan adanya perbedaan kualitas hidup antara pasien dengan penyakit tulang metastasis sebelum dan sesudah dilakukan tindakan operatif.

Metodologi: Penelitian ini merupakan penelitian kohort retrospektif pada pasien penderita penyakit tulang metastasis yang menjalani operasi yang belum pernah mendapatkan terapi apapun sebelumnya di RSUD Dr. Soetomo, Surabaya. Pengambilan sampel dilakukan secara konsekutif. Metode pengambilan data dilakukan dengan data sekunder (rekam medik), dan wawancara langsung via telepon ataupun pengisian kuesioner. Analisis dilakukan secara deskriptif dan analitik. Pengujian statistik dilakukan menggunakan uji Wilcoxon (distribusi non normal).

Hasil: Penelitian ini menganalisis 146 pasien dengan penyakit tulang metastasis. Rerata usia pasien 48,77 $\pm 13,34$ tahun. Rerata skor Karnofsky sebelum dan setelah operasi adalah 53,69 $\pm 13,07$ dan 75,54 $\pm 13,69(\mathrm{p}<0,001)$.

Kesimpulan: Nilai Karnofsky pasien pada pasien dengan penyakit tulang metastasis setelah tindakan operatif memiliki rerata lebih tinggi dibandingkan dengan sebelum tindakan operatif. Kata Kunci : Penyakit tulang metastasis, operatif, kualitas hidup, nilai Karnofsky

\begin{abstract}
Background: Metastatic bone disease is bone pathologic process caused by spread of primary tumor. The incidence of metastatic bone disease varies between $20-75 \%$ corresponds to the primary site of the malignancy. Surgery in metastatic bone disease aim to cure or palliate the morbidity caused by the disease. Operative treatment could reduce pain, improve function, control metastatic focus of the malignancy, and provide mechanical stabilization. Based on those benefits, operative treatment is important to improve quality of life in patients with metastatic bone disease.

Purpose: Proved that there was a difference in the quality of life MBD patients before and after surgery.
\end{abstract}


Methods: This research was a retrospective cohort on MBD patients which undergone surgery, and never given any other treatment in the course of the disease. The research was conducted in Dr. Soetomo General Hospital, Surabaya. Patient sampling was done using consecutive sampling. Karnofsky score was taken from the medical record before the procedure and direct interview via phone or completing questionnaire. Data analysis was done descriptively and analytically. Statistical tests were done using Wilcoxon test.

Results: 146 patients enrolled in the research. The mean age of the sample was $48.77 \pm 13.34$ years. The mean of Karnofsky score before and after the procedure was 53.69 \pm 13.07 and $75.54 \pm 13.69$ with statistical result of $\mathrm{p}<0.001$.

Conclusion: The Karnofsky score in MBD patients was higher after the surgery compared to before the surgery.

Keyword: Metastatic bone disease, operative treatment, quality of life, Karnofsky score

\section{PENDAHULUAN}

Penyakit tulang metastasis merupakan proses patologis pada tulang yang diakibatkan oleh penyebaran keganasan primer pada organ lain. Mekanisme penyebaran keganasan tersebut diketahui antara lain hilangnya kohesi interseluler, migrasi sel, angiogenesis, dan hilangnya respon imun tubuh. Tulang menduduki organ urutan ke tiga yang menjadi lokasi metastasis setelah paru-paru dan hati. ${ }^{1,2}$

Insidensi penyakit tulang metastasis beragam untuk masing-masing keganasan primernya. Macedo et al melaporkan insidensi relatif pada pasien dengan keganasan pada payudara adalah $65-75 \%$, $65-75 \%$ pada keganasan prostat, $60 \%$ pada keganasan kelenjar tiroid, 30-40\% pada keganasan paru-paru, 20-25\% pada karsinoma sel ginjal, dan $14-45 \%$ pada melanoma maligna. ${ }^{1}$ Keluhan yang muncul pada penyakit metastasis tulang seringkali ditandai dengan nyeri hebat pada tulang, gangguan mobilitas, fraktur patologis, kompresi sumsung tulang belakang, dan hipokalsemia.

Menurut Narayanan et al terdapat 3 tipe lesi pada metastasis tulang, yaitu tipe osteolitik, tipe osteoblastik, dan tipe campuran. Tetapi, apapun jenis dan asal tumornya akan menghasilkan dampak nyeri yang sama pada metasis tulang. Sehingga nyeri menjadi indikator yang sangat penting dalam menentukan kualitas hidup penderita penyakit tulang metastasis. ${ }^{3}$

Saat ini, operasi menjadi pilihan dalam penanganan penyakit tulang metastasis. Tindakan operatif dapat bertujuan untuk kuratif maupun paliatif. Tindakan operatif dapat menghilangkan rasa sakit, mengembalikan fungsi, dan juga kontrol fokus metastasis lokal dan stabilisasi mekanik tulang. Eksisi fokus metastasis membutuhkan proses mencakup kuretase, high-speed drilling, dan reseksi segmen tulang yang terkena. Tindakan operatif secara umum memiliki risiko antara lain pendarahan, risiko infeksi, dan rekurensi 
lokal. Risiko tersebut harus dipertimbangkan ketika fokus metastasis pada tulang tidak dapat dikendalikan secara non operatif. ${ }^{4}$ Untuk hal tersebut, pengukuran nilai kualitas hidup dilakukan dengan menggunakan nilai Karnofsky. ${ }^{5}$ Tharmalingam et al menjabarkan keakuratan nilai Karnofsky dalam mengukur kualitas hidup secara mandiri. ${ }^{6}$

Berdasarkan hal tersebut, keuntungan tindakan operatif bagi pasien dengan penyakit tulang metastasis penting untuk diketahui, disamping adanya risiko tindakan operasi yang dapat terjadi.

\section{METODOLOGI PENELITIAN}

Penelitian ini merupakan penelitian kohort retrospektif. Pasien dengan diagnosis penyakit tulang metastasis dengan kriteria inklusi: (1) memiliki skor Abdurachman $\geq$ 25 dan akan menjalani terapi operatif, (2) bersedia untuk mengikuti penelitian, wawancara, dan diperiksa, (3) memiliki hasil laboratorium pre-operatif kadar hemoglobin normal, fungsi ginjal normal, fungsi hati normal, dan kadar albumin normal, (4) belum pernah mendapat terapi apapun sebelumnya, dan (5) memiliki data rekam medis yang lengkap. Pasien dieksklusikan dari penelitian jika pasien: (1) tidak bersedia mengikuti penelitian, (2) memiliki diagnosis penyerta selain penyakit tulang metastasis, (3) pernah mendapatkan kemoterapi, dan (4) dalam pengobatan antinyeri opioida kuat. Skor Abdurachman digunakan sebagai kelayakan operasi.

Sampel penelitian dilakukan secara konsekutif (consecutive sampling) pada pasien yang dirawat di RSUD Dr Soetomo Surabaya. Pengambilan data dilakukan dua kali, yakni sebelum dan sesudah operasi. Pengambilan data sebelum operasi dilakukan secara sekunder dari rekam medik pasien. Pengambilan data sesudah operasi dilakukan dengan wawancara via telepon dan pengisian kuesioner pada pasien. Seluruh pengambilan data diperlakukan sama untuk menghindari bias karena adanya perbedaan perlakuan. Data penelitian yang didapat dianalisis dengan program SPSS versi 22.0 (IBM Corp, New York, United State). Uji kenormalan data (distribusi) dilakukan dengan uji Kolmogorov-smirnoff. Uji statistik $\mathrm{T}$ berpasangan dilakukan jika distribusi data normal. Uji Wilcoxon dilakukan jika distribusi data ditemukan tidak normal. 


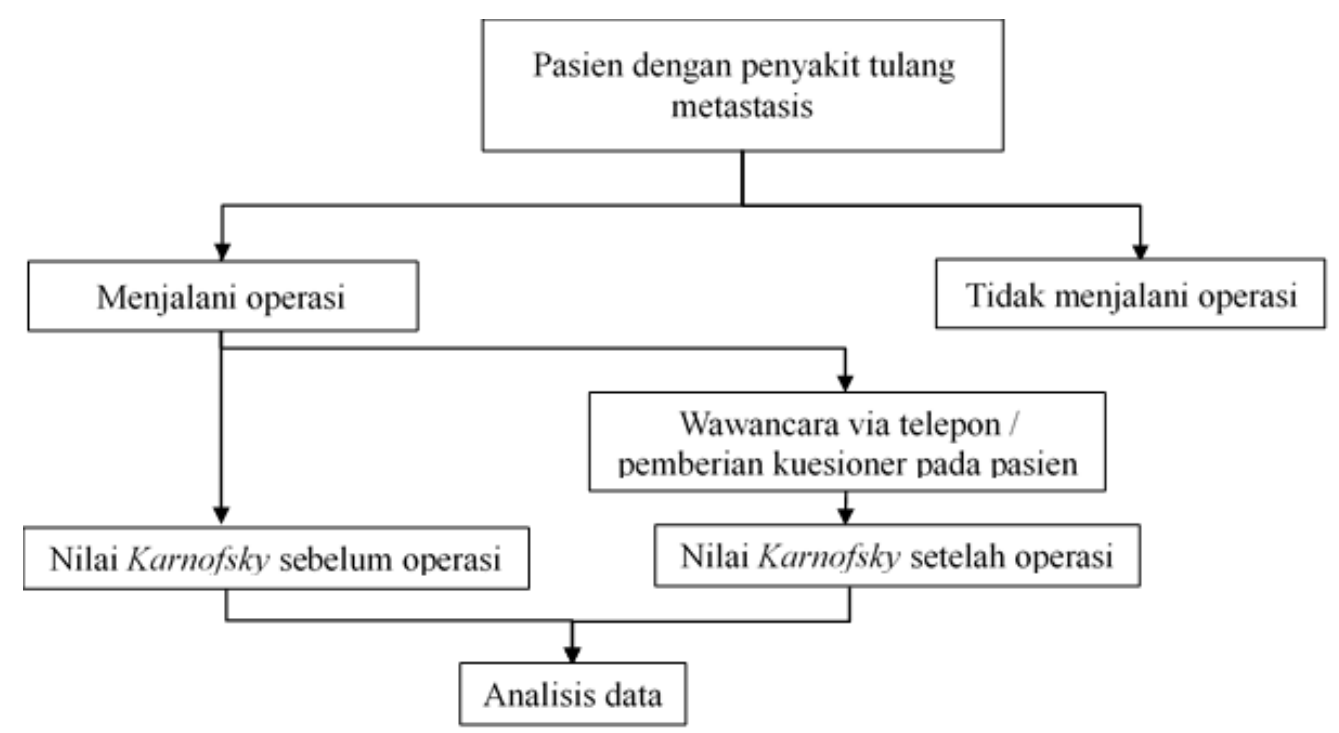

Gambar 1. Alur penelitian

\section{HASIL DAN PEMBAHASAN}

Pada penelitian ini dilakukan analisis terhadap 146 pasien dengan penyakit tulang metastasis, yang terdiri dari 71 pasien laki-laki $(48,6 \%)$ dan 75 pasien perempuan $(51,4 \%)$. Rerata usia sampel penelitian 48 tahun.

Rerata skor Karnofsky pasien sebelum operasi adalah 53,69 dan setelah operasi 75,54. Uji kenormalan distribusi data dengan uji Kolmogorov-smirnoff menunjukkan data tidak terdistribusi normal $(\mathrm{p}<0,05)$.

Uji statistik Wilcoxon menunjukkan adanya perbedaan signifikan antara skor Karnofsky sebelum dan setelah operasi ( $\mathrm{p}<0,001)$. Pengelompokkan nilai Karnofsky dengan kategori tidak dapat merawat diri (040), tidak dapat bekerja (50-70), dan aktivitas normal (80-100), sebelum dan setelah operasi menunjukkan mayoritas peningkatan dari kategori tidak dapat bekerja (sebelum operasi 71,2\%) menjadi aktivitas normal (setelah operasi 60,3\%).

Tabel 1. Karakteristik sampel dan nilai Karnofsky

\begin{tabular}{|c|c|}
\hline Karakteristik & $\mathbf{N}(\%)$ \\
\hline \multicolumn{2}{|l|}{ Jenis kelamin } \\
\hline - Laki-laki & $71(48,6 \%)$ \\
\hline - Perempuan & $75(51,4 \%)$ \\
\hline Usia & $48,77 \pm 13,34$ tahun \\
\hline
\end{tabular}

Tabel 2. Nilai Karnofsky sebelum dan setelah operasi

\begin{tabular}{cccc}
\hline & $\begin{array}{c}\text { Sebelum } \\
\text { operasi } \\
\pm \text { Standar } \\
\text { deviasi) }\end{array}$ & $\begin{array}{c}\text { Setelah } \\
\text { operasi } \\
( \pm \text { Standar } \\
\text { deviasi) }\end{array}$ & p \\
\hline $\begin{array}{c}\text { Nilai } \\
\text { Karnofsky }\end{array}$ & $53,69 \pm 13,07$ & $75,54 \pm 13,69$ & $<0,001$ \\
\hline $\begin{array}{l}\text { *terdapat } \\
\text { penurunan nilai Karnofsky dan 1 sampel yang tidak } \\
\text { mengalami perubahan nilai Karnofsky. }\end{array}$ &
\end{tabular}


Tabel 3. Karakteristik kategori nilai Karnofsky sebelum dan setelah operasi

\begin{tabular}{cc}
\hline \multicolumn{3}{c}{ Karakteristik } & $\mathbf{N}(\boldsymbol{\%})$ \\
\hline Sebelum operasi & \\
$\bullet \quad$ Tidak dapat merawat diri & $40(27,4 \%)$ \\
$\bullet \quad$ Tidak dapat bekerja & $104(71,2 \%)$ \\
$\bullet \quad$ Aktivitas normal & $2(1,4 \%)$ \\
\hline Total & \\
\hline Setelah Operasi & $146(100 \%)$ \\
$\bullet \quad$ Tidak dapat merawat diri & $5(3,4 \%)$ \\
• Tidak dapat bekerja & $53(36,3 \%)$ \\
$\bullet \quad$ Aktivitas normal & $88(60,3 \%)$ \\
\hline Total & $146(100 \%)$ \\
\hline
\end{tabular}

\section{PEMBAHASAN}

Metastasis tulang adalah penyebab morbiditas dan skeletal yang signifikan pada banyak pasien dengan keganasan. Pilihan perawatan untuk metastasis tulang telah diperluas untuk memasukkan intervensi orthopedi, generasi baru bifosfonat dan terapi sistemik. Dengan kemajuan terbaru dalam pilihan pengobatan yang efektif dan pendekatan multidisiplin untuk manajemen kanker, kelangsungan hidup pasien dengan metastasis tulang telah meningkat. Akibatnya, semakin banyak orang yang hidup lebih lama dengan metastasis tulang dan kebutuhan untuk memaksimalkan kualitas hidup mereka selama tahun-tahun ini sangat penting. Waktu kelangsungan hidup pasien sangat bergantung pada jenis kanker primer dan jenis metastasis sistemiknya. ${ }^{7-9}$

Selama beberapa tahun terakhir, lebih banyak perhatian diarahkan untuk meningkatkan perawatan paliatif pasien kanker dengan penyakit tulang metastasis.
Rekomendasi pengobatan operatif saat ini terutama didasarkan pada penelitian retrospektif dari institusi tunggal tetapi seri pasien ini sering berjumlah sedikit dan dikumpulkan selama periode waktu yang panjang. Kebanyakan penelitian berhubungan dengan metastasis tulang di tulang belakang atau metastasis tulang di ekstremitas karena perbedaan morbiditas dan pengobatan. ${ }^{10}$

Pada penelitian ini ditemukan adanya peningkatan nilai Karnofsky. Hasil uji statistik pada rerata nilai Karnofsky sebelum dan sesudah operasi menunjukkan perbedaan yang signifikan antara nilai Karnofsky sebelum dan sesudah operasi. $(\mathrm{p}=<0,001)$. Meskipun peningkatan rerata nilai Karnofsky tersebut bermakna secara statistik, terdapat 4 pasien yang mengalami penurunan nilai Karnofsky dan 1 pasien yang mempunyai nilai Karnofsky yang tetap. Hal tersebut dapat disebabkan oleh faktor internal pasien, seperti usia dan faktor komorbid pasien yang dapat membuat kualitas hidup pasien tidak lebih baik sebelum operasi.

Sebelum pasien menjalani operasi, pasien paling banyak mempunyai nilai dalam kategori tidak dapat bekerja dan masih terdapat 40 pasien yang tidak dapat merawat diri. Pasien memiliki kualitas hidup yang sangat jelek saat sebelum menjalani operasi. Setelah menjalani operasi, pasien paling banyak mempunyai nilai dalam 
kategori aktivitas normal. Hal tersebut menunjukkan peningkatan yang sangat besar pada jumlah pasien di kategori aktivitas normal pada sebelum dan setelah operasi (hanya 2 pasien menjadi 88 pasien). Selain itu, juga ditemukan penurunan kategori tidak dapat merawat diri pada sebelum dan setelah operasi (40 pasien menjadi 5 pasien). Pada kategori tidak dapat bekerja juga ditemukan temuan serupa (104 pasien menjadi 53 pasien) yang menunjukkan perbaikan kualitas hidup pasien lebih dari setengah jumlah sebelumnya. Hasil dari penelitian ini berbeda dengan temuan Hansen et al, yakni nilai Karnofsky yang buruk setelah operasi pada pasien dengan penyakit tulang metastasis daerah pelvis dan ekstremitas. ${ }^{11}$

Tindakan operatif pada penyakit tulang metastasis dalam penelitian ini menunjukkan adanya perbaikan kualitas hidup, sehingga manfaat terapi operatif dapat memberikan dampak signifikan di RSUD Dr. Soetomo. Meskipun demikian, terbatasnya sampel, serta tidak adanya kontrol membatasi generalisasi hasil tersebut.

\section{KESIMPULAN DAN SARAN}

Hasil evaluasi dengan menggunakan nilai Karnofsky pada pasien dengan penyakit tulang metastasis setelah tindakan operatif di RSUD Dr. Soetomo Surabaya menunjukkan bahwa nilai Karnofsky pasien setelah tindakan operatif memiliki rerata lebih tinggi dibandingkan dengan sebelum tindakan operatif.

\section{REFERENSI}

1. Macedo F, Ladeira K, Pinho F, et al. Bone Metastases: An Overview. Oncol Rev. 2017;11(1):321.

2. He YF, Luo HQ, Wang W, et al. Clinical features and prognosis-associated factors of non-small cell lung cancer exhibiting symptoms of bone metastasis at the time of diagnosis. Oncol Lett. 2015 Jun;9(6):2706-2712.

3. Narayanan, V, Koshy, C. Metastatic Bone Disease - A Review of Literature. Asian Journal of Cancer Vol. 8 No. 4. October 2009 pp 257-268

4. Bickels J, Dadia S, Lidar Z. Surgical management of metastatic bone disease. $J$ Bone Joint Surg Am. 2009;91(6):1503-1516.

5. Péus D, Newcomb N, Hofer $S$. Appraisal of the Karnofsky Performance Status and proposal of a simple algorithmic system for its evaluation. BMC Med Inform Decis Mak. 2013; 13:72.

6. Tharmalingam S, Chow E, Harris K, Hird A, Sinclair E. Quality of life measurement in bone metastases: A literature review. J Pain Res. 2008; 1:49-58.

7. Jehn CF, Diel IJ, Overkamp F, et al. Management of Metastatic Bone Disease Algorithms for Diagnostics and Treatment. Anticancer Res. 2016;36(6):2631-2637.

8. Szendrői M, Antal I, Szendröi A, et al. Diagnostic algorithm, prognostic factors and surgical treatment of metastatic cancer diseases of the long bones and spine. EFFORT Open Rev. 2017; 2:372-381.

9. Chow E, Finkelstein JA, Sahgal A, et al. 2014. Chapter 126: Metastatic Cancer to the Bone. In: DeVita VT, Hellman S, Rosenberg SA (eds). Principles and Practice of Oncology, 10th Edition. 
Philadelphia, PA: Lippincott, Williams and Wilkins

10. Tharmalingam S, Chow E, Harris K, Hird A, Sinclair E. Quality of life measurement in bone metastases: A literature review. Journal of Pain Research 2008: 1 49-58

11. Singh VA, Haseeb A, Alkubaisi AA. Incidence and outcome of bone metastatic disease at University Malaya Medical Centre. Singapore Med J 2014;55(10): 539-546. 